Article

\title{
Technology Innovation System Analysis of Electricity Smart Metering in the European Union
}

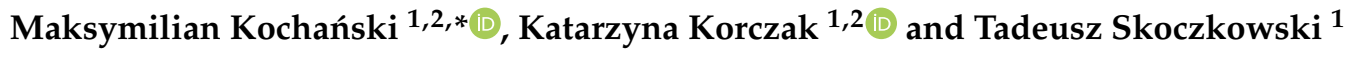 \\ 1 Faculty of Power and Aeronautical Engineering, Warsaw University of Technology, 00-665 Warsaw, Poland; \\ kkorczak@itc.pw.edu.pl (K.K.); tskocz@itc.pw.edu.pl (T.S.) \\ 2 Research and Innovation Centre Pro-Akademia; 95-050 Konstantynów Łódzki, Poland \\ * Correspondence: mkochanski@itc.pw.edu.pl; Tel.: +48-42-636-12-26
}

Received: 22 January 2020; Accepted: 11 February 2020; Published: 18 February 2020

check for updates

\begin{abstract}
Between 2018 and 2023 the penetration rate of electricity smart meters in the European Union (EU) is expected to grow from approximately $44 \%$ to $71 \%$. The unprecedently rapid development of smart metering (SM) as an ICT-enabled technological novelty is progressing in a complex, multi-actor innovation system, which is strongly driven by EU-level institutions and policies. This paper presents the comprehensive Technology Innovation System (TIS) analysis of electricity SM development in the EU, with a focus placed on regulatory aspects. The article identifies the key elements of the SM innovation system (technologies and infrastructures; actors and networks; institutions and policies) and characterises their interaction based on an in-depth desk research and a critical assessment of regulations, statistics and primary and grey literature sources (e.g., market reports). The main enablers and barriers for EU-level SM TIS development are studied. The major driving force for EU-level SM TIS is the clear, yet evolving vision of EU-level actors for the SM deployment, founded on the grounds of energy conservation and empowerment of customers. On the other hand, the major inhibitor is the insufficient regulatory framework for roll-outs at the level of a Member State, which does not fully ensure interoperability, data protection and security standards or organisational effectiveness.
\end{abstract}

Keywords: smart meter; smart metering; technology innovation system; EU; electricity metering

\section{Introduction}

Smart metering (SM) has multiple definitions [1-5]. A common understanding of SM considers it as a combination of an electronic meter and a communication link. An electronic meter computes how much energy is consumed based on electronic signals and sends this information to other devices. Smart meters are predominantly based on wireless technologies to allow for a two-way communication between a user and a utility supplier. It converts end users into energy customers who become aware of individual energy consumption and it enables them to undertake appropriate actions directly, aiming at energy consumption reduction with different second order objectives, like minimising the energy cost, meeting environmental goals or increasing local energy security. From a technical perspective, SM can be considered as a control system with the role of providing feedback to the energy system participants.

There are two key aspects characterising SM as a technological system. The first one, which is grounded in the definition proposed in the United Kingdom (the UK), focuses on the technical capabilities: Smart metering is designed to provide utility customers information on a real time basis about their domestic energy consumption. This information includes data on how much gas and electricity they are consuming, how much it is costing them and what impact their consumption is having on greenhouse gas emissions [4]. 
The second key aspect characterising SM as a technological system, which is grounded in the definition proposed by the Union of the Electricity Industry EULECTRIC, is focused on objectives: in terms of guiding principles, any smart metering system introduced should be based on:

- improvement of customer service and retail market functioning for all customers and not just for a limited number;

- offering the right balance between functionalities and cost;

- being as open as possible to downstream innovation in the home "beyond the meter" [5].

Furthermore, and crucially, two thirds of the GHG emission in the EU comes from energy production and use. In light of the EU commitments towards deep decarbonisation, fostering the further penetration of ICT into the energy sector has been placed high on the EC agenda [6]. This is one of the leading themes addressed in the Clean Energy for All Europeans package proposed by the Commission in November 2016-Winter Package [7].

The overall aim of the study is to analyse the process of SM development from the point of view of its innovative role played in the EU energy system decarbonisation. The analysis of the SM innovation system focuses on three key Technology Innovation System (TIS) elements:

1. Technologies and infrastructure-to provide generalizable results on what smart metering solutions have been devised so far, whether and how they have worked and what innovative approaches are envisioned and may be advisable in the future;

2. Actors and networks-to identify key actors and networks that contribute to innovation in SM in the EU;

3. Institutions and policies-to generate insights on a spectrum of diverse policy challenges and responses in the field of SM systems within the EU.

Furthermore, the paper describes the functioning of these elements and their interaction to contribute to understanding the importance of analysing the smart metering systems in the more general context of innovation dynamics and policy design. However, the rationale behind the article is to provide a comprehensive overview of the SM TIS at the EU level and to illustrate its complexity (especially in terms of institutional environment), rather than to provide a detailed functional analysis of the SM TIS.

The objective of this study is therefore to illustrate technical, social and economic drivers and barriers to the SM development in the EU. The research points at the need for an SM analysis that goes beyond standard energy saving and management services. For example, mostly overlooked organisational and market barriers are taken into consideration. The scope of our research is limited to electricity smart meters. Even though SM is often considered only in the electricity metering context, it does not have to be so. In fact, SM-related regulations in both Energy Services Directive (ESD) [8] and in the Energy Efficiency Directive (EED) [9] concern all energy streams. SM may also embrace heat and cold, gas, water and multiutility smart metering. (See for example [10]: "Smart meters also exist for other utilities such as water. However, the Department for the Environment, Food and Rural Affairs' 2011 Water for Life White Paper concluded that there was currently no economic case for a blanket policy for smart water metering, because the benefits of metering vary across the UK").

\section{Materials and Methods}

The literature on the methods of TIS analysis is rich (e.g., [11-13]). In this article we identify the key elements of the SM innovation system in the EU and characterise their interaction based on a set of functions of the innovation approach inspired by [14]. In reference to the conclusions of Dehdarian [15] indicating that institutional environment (e.g., standards, regulations) may reduce the possibility of selecting or combining different scenarios under TIS dynamics modelling, we focus our analysis on structural aspects of SM Technology Innovation System and in particular on its institutional elements. 
Our analysis involves political, technological, economic, regulatory and societal aspects. We use the following research methods in relation with the distinct research areas.

In the first research area, concerning technologies, infrastructures and knowledge, we perform analysis of historical development of SM technology and in particular technological trajectories, technological infrastructures and market development level, based on critical analysis of available statistics and grey literature (e.g., market research reports) concerning SM.

In the second research area, concerning actors and networks, we perform mapping of key actors (i.e., government departments and agencies, regulators, industry groups, commercial organizations, consumers, academics), based on identification of stakeholders included in both primary literature (monographs concerning SM or smart grids) and grey literature (market research reports, as in the first research area) as well as in regulations.

In the third research area, concerning our priority focus institutions and policies, we perform assessment of policy instruments that affect SM TIS development in the EU, based on an in-depth review of litereature and policies. Our research follows the classification of low carbon policy instruments developed within INNOPATHS project [16]. This allows the results of the analysis to be user-friendly to both academics and policy makers. The assessment follows three-tiers. The first-tier covers regulations, economic and financial instruments and soft instruments. The second-tier concerns policy instruments that are addressed in the decarbonisation studies and practice at a high level. The third-tier concerns policy instruments recognisable to specific types of researchers, but most essentially, to policy makers. We have excluded from the analysis five policy instruments from the INNOPATHS classification that have been considered as not applicable for SM TIS (i.e., emissions standards, funds to sub-national governments, auctions, green certificates and comparison labels).

The discussion of our results is provided from the perspective of the following functions of TIS and the related research questions:

- Innovating actors: what sector (public, private, etc.) is driving the innovation system? Do the actors have common interest in developing the system? Do these actors act as barriers for further developments of the innovation system?

- Knowledge development and exchange: what are the main barriers and enablers for knowledge exchange between science, industry and users? Are there bottlenecks to knowledge exchange?

- Actors' vision and expectation: is there a clear vision for this technology in terms of both industrial design and goals? What are the overall expectations of development? Are the vision and expectations changing over time?

- Market formation and governance processes: are there principal elements in the policy instruments landscape? Are there any significant barriers?

- Resources and sustainability: is there a sufficient amount of material, human (labor) and financial resources? Is the infrastructure developed enough or does it represent a barrier?

Our study thus informs on and maps how a specific innovation system and its component institutions, strategies and policy landscape have performed in generating innovation and why. Our conclusions provide identification of key drivers and inhibitors of innovation in the SM TIS in the EU as well as potential directions of further research.

\section{Results}

\subsection{Technologies, Infrastructures and Knowledge}

\subsubsection{Identification of the Key Incumbent and Novel Technologies}

The first electricity meter was patented in June 1884 by Hermann Aron, born in Kępno (Poland), a German engineer and a physicist [17]. He was the father of subsequent generations of active power meters, including the induction meters. (The induction meter is a mechanism in which the aluminum disc is set in a rotary motion (rotating around its own axis) due to the magnetic field created by the two 
coils of the vortex. A current proportional to the current consumed by the consumer flows through one of the coils and a current proportional to the mains voltage flows through the other. Coils, due to their location, generate a torque proportional to the product of instantaneous current and voltage, which is balanced by the braking torque that arises as a result of the rotation of the disc between the poles of the permanent magnet. The braking torque is proportional to the rotational speed of the disc, but it can be weakened due to damage to the permanent magnet-for example by influencing it with an external magnetic field. Induction counters count the disk's rotations-each revolution accounts for a specific amount of energy consumed. At one 24-h tariff, the induction meter has one meter that gives information about the consumed energy (kWh), and in a two-tariff system (day/night or weekend/working days), the meter has two sub-meters, separate for each tariff [18].) Furthermore, electronic (electronic meters base their operation on semiconductor integrated circuits, hence the second name for these meters is semiconductor meters), generating pulses under the influence of flowing current and applied voltage. These impulses are created in a quantity proportional to the electricity consumed and then their quantity is added up (counted) by the meter in a specific unit of time. Since the electronic meter counts densely generated pulses, not just the electric energy itself, it is much more accurate than the induction meters. Furthermore, electronic meters can be equipped with indicators of interference with an external magnetic field in order to prevent counterfeiting of energy consumption records).

The novelty of smart meter technology lies in the functionalities that are added to conventional electronic meters, which supports the claim that smart meter is an incremental innovation rather than a radical one. Advanced Metering Reading (AMR), which enables data acquisition from long distances, can be regarded as the predecessor of smart meters. The novel functions of smart meters (as compared to older metering solutions, including AMR) concern [19]:

- $\quad$ advanced data collection (using physical and wireless connection, end-to-end communication).

- $\quad$ advanced data processing (detection and diagnosis of system faults, data storage and management).

- $\quad$ advanced data use (interactive display, bi-directional metering and billing).

\subsubsection{Technological Trajectories}

Already in 2011 there were over 100 million smart meters installed around the world, with another 1 billion planned in the years to come [20]. As of 2020, the EU observes the second highest smart meter penetration rate, after North America [21,22]. Diffusion of SM systems has been progressing at various rates across the Member States since 2001, when the large-scale roll-out started in Italy. At the end of 2017 there were nine Member States where the smart meter roll-out has reached more than 50 percent of household consumers. Still, there were five Member States with no smart meters introduced in mass-scale (Figure 1, [23]). At the end of 2018 approximately $44 \%$ of customers had a smart electricity meter and the penetration rate is expected to reach $58 \%-71 \%$ by 2023 [21,22]. In 2018 SM constituted around $87 \%$ of the total electricity meter shipments in the EU+2 (EU-28 + Norway and Switzerland) [24].

\subsubsection{Complementary and Substitute Technologies}

The main complementary technologies for SM in the EU are Information and Communication Technologies (ICT). PLC has been the leading technology for SM communication in the first wave of SM deployments [25]. However, various other types of communication technologies for SM are also used currently (Table 1). They offer different types of advantages and entail different disadvantages, depending on the location and other circumstances of SM deployment [24,26,27]. The wireless communication technologies (e.g., mesh radio, NB-IoT) are becoming more and more advanced, offering broader bandwidth, shorter response times, improved security, as well as wide coverage, even in problematic locations, such as rural areas or cellars [24]. 


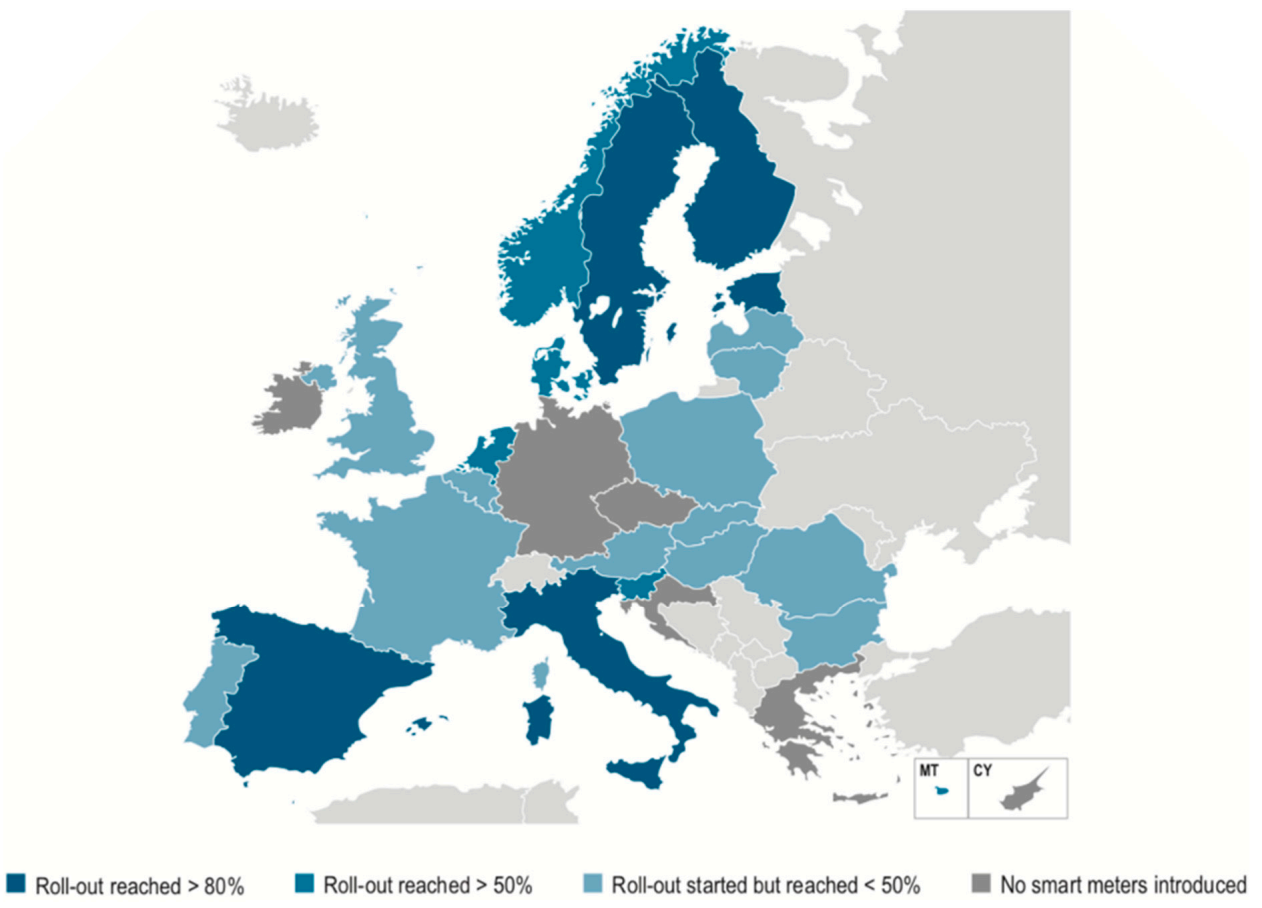

Figure 1. Electricity smart meter roll-out rates in EU MSs and in Norway in 2017 (\%). Reproduced with permission from the Agency for the Cooperation of Energy Regulators and the Council of European Energy Regulators, ACER and CEER, Annual Report on the Results of Monitoring the Internal Electricity and Natural Gas Markets in 2017. s.l.: ACER/CEER, 2018

Table 1. Communication technologies used in smart metering (SM) in the EU (Authors' work based on [23,27]).

\begin{tabular}{|c|c|c|c|}
\hline $\begin{array}{l}\text { Connection } \\
\text { Type }\end{array}$ & $\begin{array}{l}\text { Technology } \\
\text { Category }\end{array}$ & $\begin{array}{l}\text { Technology } \\
\text { Name }\end{array}$ & $\begin{array}{c}\text { Examples of Deployments in } \\
\text { SM Systems in the EU }\end{array}$ \\
\hline \multirow{11}{*}{ Wireless } & RF-Mesh & - & InovGrid $(\mathrm{PT})$ \\
\hline & \multirow{3}{*}{ Cellular } & $3 G-4 G$ & HEDNO (GR) \\
\hline & & GSM & Telegestore (IT) \\
\hline & & GPRS & PRICE-GEN (ES), Eandis and Infrax (BE), Linky (FR) \\
\hline & \multirow{3}{*}{$\begin{array}{l}\text { IEEE } 802.15 \\
\text { Group }\end{array}$} & ZigBee & \multirow{3}{*}{$\begin{array}{l}\text { Energy Demand Research Project, EDRP (UK) } \\
\text { National Smart Metering Programme, NSMP (IRL) }\end{array}$} \\
\hline & & 6LoWPAN & \\
\hline & & Bluetooth & \\
\hline & \multirow{3}{*}{$\begin{array}{l}\text { IEEE } 802.11 \\
\text { Group }\end{array}$} & Wi-Fi & \multirow{3}{*}{ National Smart Metering Programme (IRL) } \\
\hline & & Enhanced Wi-Fi & \\
\hline & & IEEE $802.11 \mathrm{n}$ & \\
\hline & IEEE 802.16 & WiMAX & Smartcity Malaga (ES) \\
\hline \multirow{7}{*}{ Wired } & \multirow{2}{*}{$\begin{array}{l}\text { Power Line } \\
\text { Communication } \\
\text { (PLC) }\end{array}$} & NB-PLC & \multirow{2}{*}{$\begin{array}{l}\text { Telegestore (IT), PRICE-GEN, Iberdrola (ES) } \\
\text { Eandis and Infrax (BE), Linky (FR) }\end{array}$} \\
\hline & & BB-PLC & \\
\hline & \multirow{3}{*}{ xDSL } & ADSL & \multirow{3}{*}{$\begin{array}{l}\text { Demand Research Project, EDRP (UK), } \\
\text { PRICE-GEN (ES), Eandis and Infrax (BE), } \\
\text { Stadtwerke Emden by Deutsche Telekom (DE) }\end{array}$} \\
\hline & & HDSL & \\
\hline & & VHDSL & \\
\hline & Euridis & IEC 62056-31 & SMs in France \\
\hline & PON & - & PRICE-GEN (ES) \\
\hline
\end{tabular}


Between 1995 and 2015, ICTs have been growing much faster than the overall EU economy. In 2015 the ICT sector generated value added of 581 billion Euros (3.9\% of the EU value added) and employed 5.8 million people across all EU Member States (2.5\% of the employment) [28]. Considering various ICTs, the cybersecurity technologies are of particular relevance as complementary technologies for SM. Between 2018 and 2023 the EU cybersecurity market is expected to grow at a compound annual growth rate (CAGR) of $11.3 \%$ and its value is expected to exceed 40 billion Euros [29]. The main substitute technologies for SM in the EU are meters enabling remote readings but not providing key functionalities of smart meters, such as bi-directional communication.

\subsubsection{Level of Technology and Market Development}

$\mathrm{SM}$, along with the surrounding metering infrastructure, has reached a stabilisation phase. Both the technology of semiconductor meters and its technological background (data transmission and processing, communication technologies etc.) is mastered [30,31]. The European SM market is growing, yet the old (traditional) metering solutions are still dominating the majority of national markets.

Contrary to the limited potential of technology development or the core measuring aspect of $\mathrm{SM}$, there is a huge potential for development of complementary technologies and services, including the following:

- Integration of smart meters data with new elements of smart grid, e.g., distribution management systems, Volt/VAR optimisation systems, transmission grid [32,33];

- Development of new services for end users based on real-time analytics, demanding smart metering data integration with nonstandard data sources [32,33];

- Outsourcing of the data functions of smart metering by large utilities to small companies, often start-ups [32];

- Market fragmentation into three types of companies:

- Utilities providing a full spectrum of advanced metering infrastructure, beyond smart metering;

- Companies specializing in smart metering, working on expanding their applicability;

$\bigcirc \quad$ Companies focused on offering only managed services and system integration, based on products from other producers [32];

- Further development and scaling-up of meter data management systems-extension to support complex analytics solutions [32,33];

- Modification of existing systems to support future needs of a system operator and customers, e.g., management of new asset classes, new billing options [33];

- Further development of communication protocols, e.g., more flexible networks to support different types of data traffic, development of open standards, security issues improvements, supporting other smart grid technologies [33].

\subsection{Actors and Networks}

Large number of stakeholders is a characteristic feature of the EU SM innovation system (Table 2).

\subsection{Institutions and Policies}

This section analyses and assesses the regulations, economic and financial instruments and soft instruments addressing SM at the EU level (Table 3). 
Table 2. Inventory of the main stakeholders in smart metering projects in the EU (Authors' work based on [21,34]).

\begin{tabular}{|c|c|}
\hline Type of Institution & Stakeholders \\
\hline EU organisations & $\begin{array}{r}\text { European Commission, Directorate-General for Energy (DG ENER), Directorate-General for Internal Market, Industry, } \\
\text { Entrepreneurship and SMEs (DG GROW) } \\
\text { EU Agencies, including Executive Agency for Small and Medium-sized Enterprises (EASME), EU Agency for Cybersecurity } \\
\text { (ENISA), Agency for the Cooperation of Energy Regulators (ACER) } \\
\text { Official expert advisory bodies of the European Commission, including Smart Grids Task Force (SGTF), Working Group } \\
\text { Measuring Instruments (E01349), European Multi-Stakeholders Platform on ICT Standardisation (E02758) }\end{array}$ \\
\hline \multirow{3}{*}{$\begin{array}{l}\text { Central \& local } \\
\text { decision makers }\end{array}$} & National level of government \\
\hline & Regional and local levels of government \\
\hline & Energy state agencies implementing energy and environmental policy \\
\hline \multirow{4}{*}{ Regulators } & National energy regulators \\
\hline & National telecommunication regulators \\
\hline & National personal data protection authorities \\
\hline & $\begin{array}{l}\text { Organisations and collaboration platforms of regulators, including the Council of European Energy Regulators (CEER), The } \\
\text { International Working Group on Data Protection in Telecommunications ("the Berlin Group"), European Data Protection } \\
\text { Board (EDPB) }\end{array}$ \\
\hline \multirow{3}{*}{$\begin{array}{l}\text { Standardisation } \\
\text { bodies }\end{array}$} & National standardisation bodies, working in close co-operation with international standardisation bodies \\
\hline & $\begin{array}{l}\text { International standardisation organisations, including the European Committee for Standardization CEN, the European } \\
\text { Committee for Electrotechnical Standardisation CENELEC, the European Telecommunications Standards Institute ETSI, } \\
\text { the European Environmental Citizens Organisation for Standardisation ECOS, the Smart Meters Coordination Group SM-CG }\end{array}$ \\
\hline & Stakeholders providing experts for standardisation works \\
\hline \multirow{2}{*}{$\begin{array}{l}\text { Industry as } \\
\text { manufactures and } \\
\text { service providers }\end{array}$} & $\begin{array}{l}\text { Smart meters and other AMI components manufacturers, including Itron, Landis+Gyr, Honeywell, Aclara Technologies, } \\
\text { ADD Grup, AEM, Aidon, Apator, Circutor, Diehl Metering, EDMI Meters, Elgama Elektronika, EMH Metering, Flonidan, } \\
\text { Hager, Hexing Electrical, Iskraemeco, Janz, Kaifa Technology, Kamstrup, Linyang Energy, MeteRSit, Networked Energy } \\
\text { Services, NIK, Pietro Fiorentini, RIZ, Sagemcom, Sanxing Electric, Wasion, ZIV, ZPA Smart Energy [23] }\end{array}$ \\
\hline & $\begin{array}{c}\text { Communication solutions providers, including APKAPPA, CyanConnode, Devolo, NURI Telecom, Ormazabal, Power Plus } \\
\text { Communications, Sensus, Trilliant, Toshiba, Xemex }\end{array}$ \\
\hline
\end{tabular}


Table 2. Cont

\begin{tabular}{|c|c|}
\hline Type of Institution & Stakeholders \\
\hline & Software solutions providers, including Cuculus, EnoroCX, Ferranti, Görlitz, Kisters, Oracle, Powel, SAP, Telecontrol STM \\
\hline & $\begin{array}{l}\text { System integrators and communication service providers, including: A1 Telekom Austria, Arkessa, Arqiva, Atos, } \\
\text { Capgemini, CGI, Com4, IBM, LG CNS, Schneider Electric, Siemens, Telecom Italia, Telefónica, UtilityConnect, Vodafone }\end{array}$ \\
\hline & $\begin{array}{l}\text { Associations of Industry, including the European Smart Metering Industry Group ESMIG, the European Network for Cyber } \\
\text { Security ENCS, the European Utilities Telecom Council EUTC, Orgalim-Europe's Technology Industries, EBIX, the European } \\
\text { forum for energy Business Information eXchange, Wi-SUN Alliance }\end{array}$ \\
\hline Energy Sector & $\begin{array}{c}\text { Transmission System Operators } \\
\text { Distribution System Operators } \\
\text { Energy suppliers } \\
\text { Large energy producers } \\
\text { Individual small and medium energy producers } \\
\text { Associations of energy sector, including: European Federation of Local Energy Companies CEDEC, European Distribution } \\
\text { System Operators EDSO, European Network of Transmission System Operators for Electricity ENTSO-E, Union of the } \\
\text { Electricity Industry EURELECTRIC, European Energy Retailers EER, Verband der unabhängigen Strom- und } \\
\text { Gasverteilerunternehmen GEODE, SmartEn (formerly: Smart Energy Demand Coalition SEDC) }\end{array}$ \\
\hline $\begin{array}{l}\text { Research, } \\
\text { Development and } \\
\text { Innovation sector }\end{array}$ & R\&D\&I providers (universities, public and private research entities, NGOs, etc.), including EC Joint Research Centre \\
\hline End-users & $\begin{array}{l}\text { Large industrial customers } \\
\text { Nonresidential small and medium customers (industrial, commercial, etc.) } \\
\qquad \text { Residential customers } \\
\text { Public services sector }\end{array}$ \\
\hline Financial institutions & $\begin{array}{c}\text { European Investment Bank (EIB), European Bank for Reconstruction and Development (EBRD), other financial institutions } \\
\text { providing financing of SM deployments }\end{array}$ \\
\hline
\end{tabular}


Table 3. Assessment of the EU-level policy instruments addressing smart metering Technology Innovation System (TIS) (source: Authors' work, following classification

of policy instruments developed by [16]).

\begin{tabular}{|c|c|c|c|c|c|}
\hline \multicolumn{3}{|c|}{ Policy Instrument } & \multicolumn{3}{|c|}{ Assessment of the Instrument } \\
\hline & & & $\begin{array}{c}\text { Not Used/ } \\
\text { Underdeveloped/ } \\
\text { Implementation Delayed }\end{array}$ & $\begin{array}{c}\text { Used in a Limited } \\
\text { Extent/not Effectively, } \\
\text { Plans Exist }\end{array}$ & Actively Used \\
\hline \multirow{7}{*}{ Regulation } & \multirow{4}{*}{ Codes/standards/mandates } & Building codes and standards & $\mathrm{x}$ & & \\
\hline & & Product standards & & $x$ & \\
\hline & & Sectoral standards & & & $x$ \\
\hline & & Auditing & & $\mathrm{x}$ & \\
\hline & Obligation & Obligation schemes & & & $x$ \\
\hline & schemes/quotas & Carbon Emissions Reduction Target & $\mathrm{x}$ & & \\
\hline & Other regulation & Net metering & & & $\mathrm{x}$ \\
\hline \multirow{9}{*}{$\begin{array}{l}\text { Economic and } \\
\text { financial } \\
\text { instruments }\end{array}$} & Direct investment & Government procurement & & & $\mathrm{x}$ \\
\hline & \multirow{6}{*}{ Fiscal/financial incentives } & RD\&D funding & & & $\mathrm{x}$ \\
\hline & & Tariffs & & & $\mathrm{x}$ \\
\hline & & Grants and subsidies & & $\mathrm{x}$ & \\
\hline & & Loans/soft loans & & $\mathrm{x}$ & \\
\hline & & Taxes—tax relief/exemption & $\mathrm{x}$ & & \\
\hline & & User charges & & $\mathrm{x}$ & \\
\hline & Market-based instruments & GHG emissions allowances trading scheme & $x$ & & \\
\hline & & White certificates & $\mathrm{x}$ & & \\
\hline \multirow{7}{*}{$\begin{array}{l}\text { Soft } \\
\text { instruments }\end{array}$} & Performance labels & Endorsement label & $\mathrm{x}$ & & \\
\hline & \multirow{3}{*}{ Information campaigns } & By energy agencies & & $\mathrm{x}$ & \\
\hline & & By energy suppliers & & $\mathrm{x}$ & \\
\hline & & By other institutions & & $\mathrm{x}$ & \\
\hline & \multirow{3}{*}{ Voluntary approaches } & Negotiated Agreements (Public-private sector) & $\mathrm{x}$ & & \\
\hline & & Public Voluntary Schemes & $\mathrm{x}$ & & \\
\hline & & Unilateral Commitments (Private sector) & $\mathrm{x}$ & & \\
\hline
\end{tabular}




\subsubsection{Regulation}

Building Codes and Standards

According to Article 8 of the Directive 2010/31/EU of 19 May 2010 on the Energy Performance of Buildings, Member States shall encourage the introduction of intelligent metering systems whenever a building is constructed or undergoes major renovation, whilst ensuring that this encouragement is in line with the Directive 2009/72/EC (SM roll-out is economically reasonable and cost-effective). Still, there is no EU-level legislation for the Member States' building codes or standards that would require the installation of smart meters in buildings or provide clear guidelines for the Member States' building codes or standards as far as the smart meters are concerned [35]. Yet, in some Member States (e.g., in Poland) building codes do require installation of electricity meters in newly constructed buildings, though such meters may be of "conventional" character [36]. In view of the above, building codes and standards can be regarded as regulation instruments that are not effectively used at the EU level for SM TIS development.

\section{Product Standards}

The EED has introduced the following definition of SM system: "smart metering system" or "intelligent metering system" means an electronic system that can measure energy consumption, providing more information than a conventional meter and can transmit and receive data for information, monitoring and control purposes, using a form of electronic communication. In contrast, a "conventional meter" is defined as an analogue meter or an electronic meter with no capability to both transmit and receive data. EED Articles 9(2) and 10(2) and Article 2 of Annex I of the Electricity Directive (ED) describe requirements for electricity SM. According to Article 2 of Annex I to the Directive, the Member States, or any designated authority, should make sure that interoperability of SM systems is implemented and should have due regard to the use of appropriate standards and best practice and the importance of the development of the internal market in electricity.

To face these challenges, CEN, CENELEC and ETSI have been nominated in 2009 by the European Commission (Mandate M/441) as main institutions responsible for the development of an open utility measures architecture that enables interoperability [37]. It resulted in establishment of the Smart Meters Coordination Group (SM-CG), comprising expertise and resources of CEN, CENELEC, ETSI and European Standardization Organizations (ESOs). SM-CG acts as an advisory body for SM standardisation issues.

In the first step, the SM-CG developed a technical report focusing on communication standards that would support further development software and hardware architecture. The report identifies interfaces and functional entities that should be met by SM. Then the SM-CG put its efforts on the development of standards for unified solutions for supplementary functionalities of interoperable SM [38].

In 2012, the European Commission published its recommendations on preparation for deployment of smart metering systems [39], which addressed three main issues:

- $\quad$ protection and security of personal data (\$§ 4-29);

- $\quad$ long-term economic assessment $(\S \S 30-38)$;

- $\quad$ specification of common minimum functionalities of smart meters (\$§ 39-42) (Table 4).

In March 2019 the European Parliament approved the recast of the Directive of the European Parliament and of the Council on common rules for the internal market in electricity (EDR). The EDR was a part of the European Commission legislative package titled "Clean Energy for all Europeans" (the so-called "Winter Package"), presented on 30 November 2016. The EDR provided new regulations concerning SM. The new rules will have to be implemented in the Member States' legislations within 18 months from the final adoption of the Directive [40]. 
Table 4. Specification of common minimum functionalities of smart meters (Reproduced under CC BY 4.0, European Commission. (2012/148/EU) Commission Recommendation of 9 March 2012 on Preparations for the Roll-out of Smart Metering Systems; Brussels: European Commission, 2012).

\begin{tabular}{|c|c|}
\hline Area & Minimum Functional Requirements \\
\hline \multirow{2}{*}{ Customer } & $\begin{array}{l}\text { (1) Provide readings directly to the customer and any third party designated } \\
\text { by the consumer }\end{array}$ \\
\hline & $\begin{array}{l}\text { (2) Update the readings referred to in point (a) frequently enough to allow the } \\
\text { information to be used to achieve energy savings }\end{array}$ \\
\hline \multirow{3}{*}{ Metering operator } & (3) Allow remote reading of meters by the operator \\
\hline & $\begin{array}{l}\text { (4) Provide two-way communication between the smart metering system and } \\
\text { external networks for maintenance and control of the metering system }\end{array}$ \\
\hline & $\begin{array}{l}\text { (5) Allow readings to be taken frequently enough for the information to be } \\
\text { used for network planning }\end{array}$ \\
\hline \multirow{2}{*}{$\begin{array}{l}\text { Commercial aspects } \\
\text { of energy supply }\end{array}$} & (6) Support advanced tariff systems \\
\hline & (7) Allow remote on/off control of the supply and/or flow or power limitation \\
\hline \multirow{2}{*}{$\begin{array}{l}\text { Security and data protection } \\
\text { Distributed generation }\end{array}$} & (8) Provide secure data communications \\
\hline & (9) Provide import/export and reactive metering \\
\hline
\end{tabular}

One of the new requirements, according to Article 19 of the EDR, is that SM should enable providing output for consumer energy management systems. This can be regarded as a major regulatory step forward, as in 2018 only 12 Member States introduced mandatory interfaces of SM systems [24]. Other functionality requirements (Figure 2) and maximum time granularities for readings $(15,30$ and $60 \mathrm{~min})$ also widely differ across the EU. This diversification in technical requirements provided by the product standards may have negative influence on the transnational flow of smart meters as goods and the related services. For instance, a smart meter without integrated in-home displays may not be accepted by some Member States.

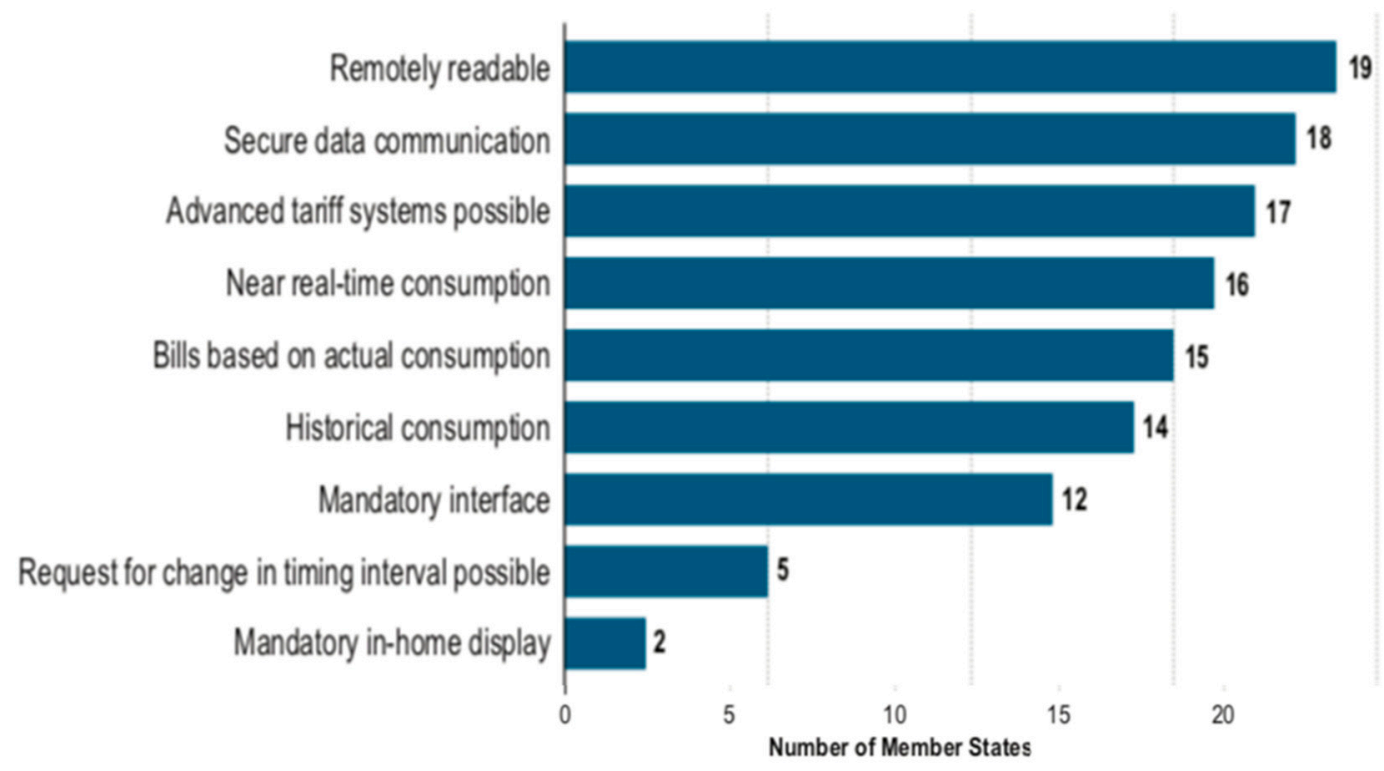

Figure 2. Most adopted legal requirements for smart meters in EU MSs-2017 (number of MSs). Reproduced with permission from the Agency for the Cooperation of Energy Regulators and the Council of European Energy Regulators, ACER and CEER, Annual Report on the Results of Monitoring the Internal Electricity and Natural Gas Markets in 2017. s.l.: ACER/CEER, 2018. 
In view of the above, product standards can be regarded as regulation instruments that are effectively used only in limited extent at the EU level to support the SM TIS development. The common minimum functional requirements for SM systems can be considered as general and not sufficiently detailed to ensure the adequate interoperability and to enable full exploitation of the EU internal market potential for cross-border flow of products and services.

\section{Sectoral Standards}

The 17 major EU-level sectoral standards concerning SM can be grouped into three categories: wired PLC standards (eight standards), wireless standards (seven standards) and standards that concern only the application layer (two standards) [41]. A relatively high number of alternative sectoral standards illustrate the growing phase of SM as a technology innovation. None of the standards is perfect in all aspects (e.g., range, interoperability, frequency bands), which suggests that selection of standard involves trade-offs [41]. The high number of competing SM sectoral standards creates several challenges, as it leaves economies of scale unrealised, creates a patchwork of different solutions and potentially results in a lack of interoperability [41]. Still, sectoral standards can be regarded as regulation instruments that are actively used at the EU level for the SM TIS development.

\section{Auditing}

To support the fulfilment of the provisions set in Annex 1 of the ED (2009/72/EC), in 2012 the European Commission's Joint Research Centre published the Guidelines for Cost Benefit Analysis (CBA) of Smart Metering Deployment [42]. The publication of the Guidelines can be regarded as the initiating step for ex-ante auditing of SM development in the EU. However, it should be noted that the CBA was envisioned as a nonrecurring assessment, not scheduled for ongoing monitoring of TIS development. The EDR [40] slightly changed the situation-now Member States shall ensure that this assessment will be revised at least every four years in cases in which the CBA had previously given negative assessment. No other auditing instruments for SM have been identified at the EU level. All in all, auditing can be regarded as a regulation instrument that is used to a limited extent at the EU level for the SM TIS development.

\section{Obligation Scheme}

The EU Directive concerning the common rules for the internal market for electricity (2009/72/EC) and the EU Directive on energy efficiency (2012/27/EU, EED) require Member States to ensure the implementation of "intelligent metering systems", where the roll-out of such systems is assessed positively. In the case that the long-term benefits outweigh the costs, at least $80 \%$ of households should have smart meters installed by 2020 . However, among the 16 Member States with the positive assessment made in 2014 (e.g., Poland), in some cases no legal date has been set yet in the relevant national legislation. On the other hand, in some Member States with the negative decision on wide-scale roll-outs taken as a result of CBA analyses from 2014 (e.g., Lithuania), there have been subsequent changes, such as setting legal dates for SM roll-outs (Figure 3).

As a result of introducing the obligation scheme, by 2020, approximately 200 million smart meters were planned to be installed in the EU, representing approximately $72 \%$ of all EU-28 consumers as of 2014 [43]. Major roll-outs were planned in Italy, France and the UK (Table 5, Figure 3). Given that over 30 million smart meters were installed at European residential buildings already in 2001, the annual diffusion rate expected in 2014 (growth rate of number of smart meters installed) was over $11 \%$ p.a.

The obligation scheme concerning SM has been complemented by numerous nonbinding policy instruments, e.g., recommendations and opinions [44-46]. Overall, the obligation scheme can be regarded as a regulation instrument that is actively used at the EU level for the SM TIS development. 


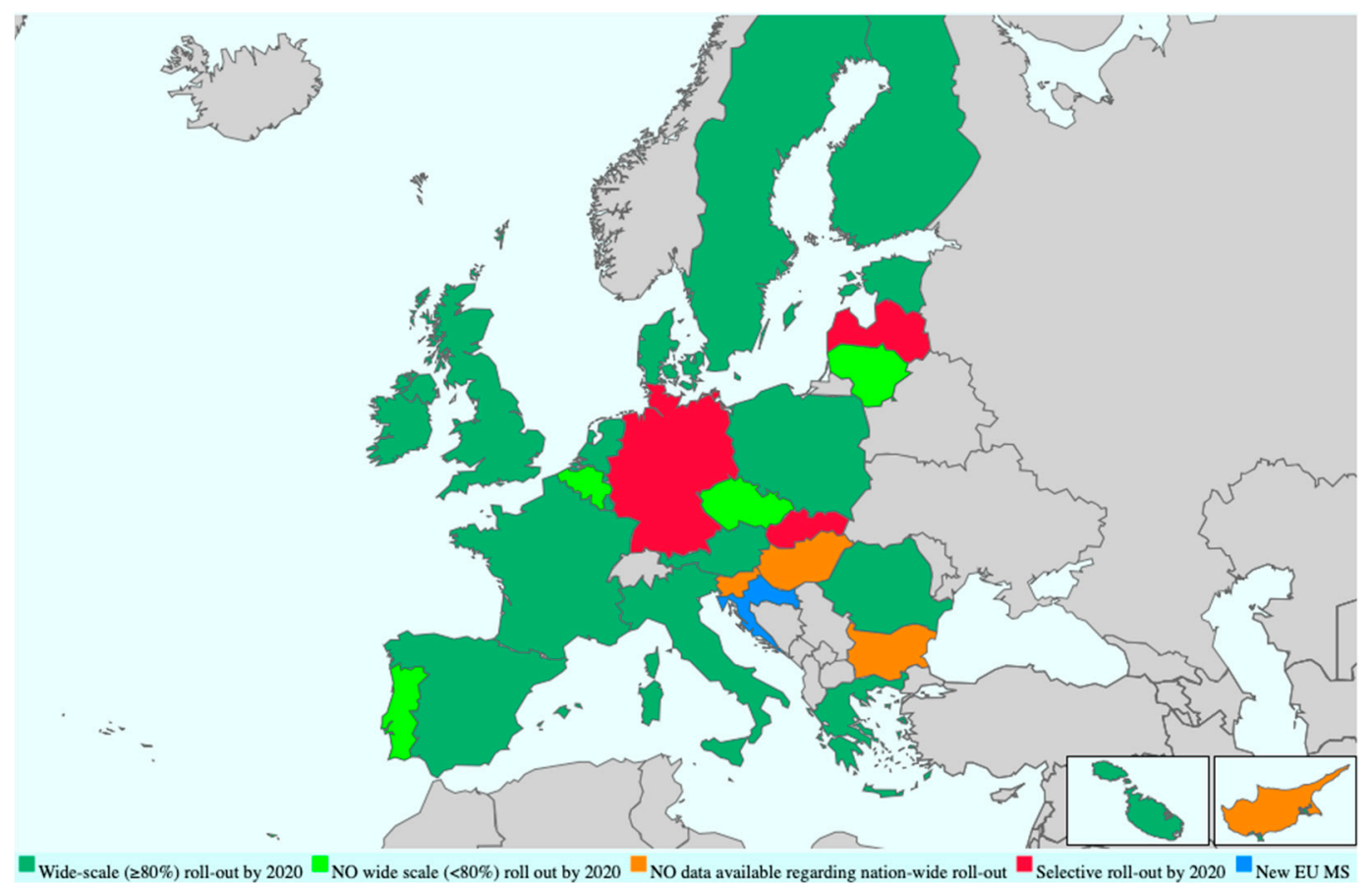

Figure 3. Decisions of EU MSs to start smart meter roll-out, as a result of cost-benefit analyses in 2014. Reproduced under CC BY 4.0, European Commission Joint Research Centre. Smart Metering Deployment in the European Union 2019. Available online: https://ses.jrc.ec.europa.eu/smart-meteringdeployment-european-union (accessed on 15 April 2019).

Table 5. Number of electricity smart meters to be installed per Member State that are proceeding with large-scale roll-out. Reproduced under CC BY 4.0, European Commission. SWD(2014) 189 Final. Cost-Benefit Analyses \& State of Play of Smart Metering Deployment in the EU-27; Brussels: European Commission, 2014.

\begin{tabular}{cccc}
\hline $\begin{array}{c}\text { Large-Scale Roll-Out } \\
\text { (at Least 80\% of } \\
\text { Consumers by 2020) }\end{array}$ & $\begin{array}{c}\text { Metering Points in } \\
\text { the Country by 2020 }\end{array}$ & $\begin{array}{c}\text { Expected Diffusion } \\
\text { Rate by 2020 (\%) }\end{array}$ & $\begin{array}{c}\text { Total Number of Smart } \\
\text { Metering Points to be } \\
\text { Installed up to 2020 }\end{array}$ \\
\hline Austria & $5,700,000$ & 95 & $5,415,000$ \\
Denmark & $3,280,000$ & 100 & $3,280,000$ \\
Estonia & 709,000 & 100 & 709,000 \\
Finland & $3,300,000$ & 100 & $3,300,000$ \\
France & $35,000,000$ & 95 & $33,250,000$ \\
Greece & $7,000,000$ & 80 & $5,600,000$ \\
Ireland & $2,200,000$ & 100 & $2,200,000$ \\
Italy & $36,700,000$ & 99 & $36,333,000$ \\
Luxembourg & 260,000 & 95 & 247,000 \\
Malta & 260,000 & 100 & 260,000 \\
Netherlands & $7,600,000$ & 100 & $7,600,000$ \\
Poland & $16,500,000$ & 80 & $13,200,000$ \\
Romania & $9,000,000$ & 80 & $7,200,000$ \\
Spain & $27,768,258$ & 100 & $27,768,258$ \\
Sweden & $5,200,000$ & 100 & $5,200,000$ \\
United Kingdom & $31,992,000$ & 99.50 & $31,832,040$ \\
Total & $192,469,258$ & 95.30 & $183,394,298$ \\
\hline
\end{tabular}

Carbon Emissions Reduction Target

No EU-level regulation setting Carbon Emissions Reduction Targets for SM has been identified. Therefore, Carbon Emissions Reduction Targets can be regarded as regulation instruments that are not used for the support of the SM TIS development at the EU level. 


\section{Net Metering}

$\mathrm{SM}$ is a crucial element of net metering, which in turn is a vital contractual arrangement for large scale RES deployment [47]. Providing import/export and reactive metering functionality is one of the nine minimum functional requirements for SM systems [39]. It thus allows for diffusion of renewables and small-scale local generation, as well as secures future metering needs. The European Commission recommends that net metering should be a fixed default option and operated on customer demand. In this context net metering can be regarded as a regulation instrument that is actively used at the EU level for support of the SM TIS development.

\subsubsection{Economic and Financial Instruments}

Direct Investment

Government procurement:

Between 2012 and 2017 a total of 416 public procurements (hereinafter referred to as government procurements) for energy meters were announced at the EU-level, mainly by utilities entities-over $75 \%$ (Figure 4). The average number of EU-level procurements for energy meters per year between 2012 and 2017 per Member State was 2.5. In this sense government procurement can be regarded as a direct investment that is actively used at the EU level for the SM TIS development.

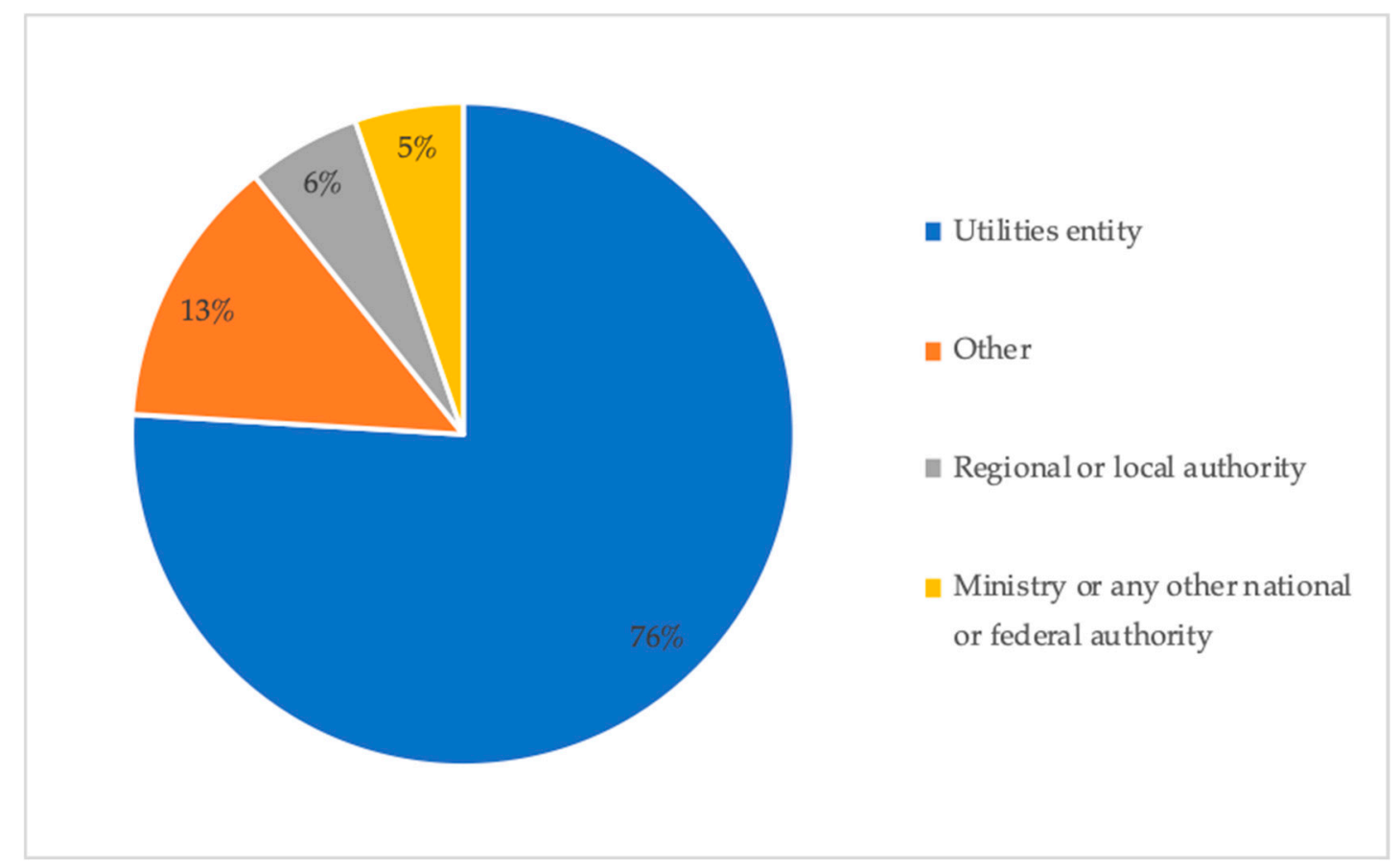

Figure 4. Notices concerning public procurement procedures for the supply of energy meters (CPV 38551000) in the EU, registered on TED, the online version of the "Supplement to the Official Journal" of the EU, dedicated to European public procurement between 1 January 2012 and 31 December 2017 (total $=416$ notices).

\section{RD\&D Funding:}

The major EU-level funding instrument for RD\&D on SM is Horizon 2020, the biggest EU Research and Innovation programme ever with a budget of nearly EUR 80 billion for the years 2014 to 2020 [48]. According to the query placed on the European Commission's CORDIS portal, as of January 2020, a total of 72 R\&D projects containing key word "smart meters" have been funded by the Horizon 2020 Programme. The projects' coordinators were based in 18 EU Member States-mainly in Italy (12), Spain (11) and the UK (8), as well as in three third countries (Iceland, Israel and Norway). In view of 
the above, RD\&D funding can be regarded as a direct investment instrument that is actively used at the EU level for the SM TIS development.

Fiscal/Financial Incentives

Tariffs:

The relation between tariffs and SM in the EU is of dual character. On the one hand, SM enables novel tariffs based on dynamic pricing, in turn contributing to reducing the peak power demand [49]. Electricity companies have already introduced dynamic price contracts in several Member States, enabling automated services, empowering households and contributing to reductions in households' energy bills, even without behavioural changes. The introduction of dynamic pricing for households with small electricity consumption has been estimated to entail $22 \%$ to $70 \%$ of energy savings [50].

On the other hand, network tariffs enable SM, as they are the most common source of financing of SM deployments in the EU [51]. The tariffs for households are still being regulated in 14 EU Member States [52]. For instance, in Poland the tariffs for households are approved by the President of the Energy Regulatory Office. In the UK, electricity prices are regulated in the form of a price cap on domestic prepayment meter charges [52]. The situation in such countries is likely to change as a result of the adoption of the EDR [40]. According to Article 5 of the EDR, there should be no restriction for energy suppliers to set the price at which they provide electricity to customers. Member States will be allowed to apply price setting only for energy poor or vulnerable household customers. Furthermore, according to Article 11 of the EDR, final customers equipped with a smart meter need to have the possibility of signing a dynamic electricity price contract with at least one provider. Furthermore, all electricity suppliers providing services to more than 200,000 final customers have to offer such contracts.

SM using time-of-use electricity price tariff (i.e., where energy is less or more expensive depending on the time of day or the weekday/weekend) is the most common type of device in the EU, available in 13 Member States. Real-time or hourly pricing (where consumer energy prices are set to match closely with wholesale prices) is also popular-it is used by eight Member States [24]. SM using remote consumption control (where the SM adjusts the functioning of certain building appliances, e.g., heat pumps, to hourly electricity prices) are available in three Member States. SM based on critical peak pricing (i.e., introducing higher electricity prices during peak consumption) are available in one Member State-France.

Tariffs, in total, can be regarded as financial instruments that are actively used at the EU level for the SM TIS development.

Grants and Subsidies:

EU-level grants and subsidies are used primarily in the implementation of regional policy. Between 2014 and 2020 it was the EU's main investment policy, worth over EUR 351 billion-almost a third of the total EU budget [53]. The major tools of the regional policy are two funds: the European Regional Development Fund (ERDF) and the Cohesion Fund (CF).

According to Article 3 of the ERDF Regulation, the ERDF shall support inter alia investment in infrastructure providing basic services to citizens in the areas of energy [54]. Similarly, according to Article 2 of the CF Regulation, the CF shall support inter alia investment in the environment, including areas related to sustainable development and energy [55]. In particular, the CF shall support smart energy management in public infrastructure, including in public buildings and in the housing sector (Article 5 of the CF regulation).

However, SM is not explicitly indicated as investment priorities of either ERDF or CF. In this context grants and subsidies can be regarded as financial instruments that are used only to a limited extent at the EU level to support SM TIS development. The lack of explicit indication of SM in the high-level EU legislation as investment priorities might be the reason for limited consideration for $\mathrm{SM}$ in the grant rules set at the operational (Member States') level. For instance, the Infrastructure and Environment Operational Programme, which has been the biggest EU investment programme in Poland between 2014 and 2020 and which was cofinanced by both the ERDF and the CF, has no 
funding line dedicated for SM roll-out. As a result, as of January 2020, no SM deployment by Polish energy suppliers has been supported using the ERDF of the CF funding [56]. However, many R\&D initiatives concerning SM are supported by the ERDF, e.g., the R\&D project system for balancing and remote reading of energy measurements using devices that provide smart meter functionality for the current infrastructure of electronic electricity meters, which has been supported by nearly EUR 1 million from the ERDF [57].

Loans/soft loans:

The major source of loans for SM deployment at the EU-level is the European Fund for Strategic Investment (EFSI), which is one of the three cornerstones of the Investment Plan for Europe (the Juncker Plan). The EFSI has been initiated jointly by the European Commission and the EIB Group to help mobilise private financing for investments. It is an arrangement between the EC and the EIB Group, based on an EU guarantee (EUR 16 billion) matched by an EIB Group capital contribution (EUR 5 billion). It is planned that EFSI will leverage EUR 60.8 billion of supplementary financing by the EIB Group, thus mobilising over EUR 315 billion for investment in the EU [58]. One of the two EFSI components is the Infrastructure and Innovation Window (IIW), implemented through the European Investment Bank. As of January 2020, the EFSI has supported 121 projects in the energy sector. However, only a few of them concern investment in SM. Some examples of these supported initiatives are:

- $\quad$ the roll-out of 7 million smart meters in the UK by Calvin Capital, a British company that ensures financing and management of the installation of smart meters (EFSI-backed financing of EUR 48 million, set to trigger total investment of EUR 2.1 billion)

- installation of advanced meters by Energa, one of the three largest electricity suppliers in Poland (EFSI-backed financing of EUR 250 million, set to trigger total investment of EUR 750 million) [59].

In view of these facts, loans can be regarded as financial incentives that are used, but in limited extent at the EU level to support the SM TIS development.

Taxes-Tax relief/exemption:

The Commission requires the Member States to either obligatorily or voluntarily exempt certain goods and services from taxation. Supplies that must be exempt concern areas of the public interest (e.g., medicines, education) [60]. However, smart meters are not included on the list of supplies that are exempt from the Value Added Tax (with the right to deduct, without the right to deduct or any other exemption) [61]. In this context tax reliefs or exemptions can be regarded as fiscal incentives that are not used at the EU level to support the SM TIS development.

User charges:

According to Article 21 of the EDR (entitlement to a smart meter), where the roll-out of smart metering systems has not been positively evaluated as a result of the CBA by the Member State and where SM systems are not rolled-out in a systematic manner, Member States must make sure that every final customer can request, while covering the necessary costs, an installation, or, where applicable, an upgrade of a smart meter. Overall, user charges can be regarded as financial instruments at the EU-level that are planned to be introduced to support the SM TIS as of 2020.

\section{Market-Based Instruments}

GHG emissions allowance trading scheme:

EU Member States' revenues acquired from the GHG emissions allowance trading scheme between 2012 and 30 June 2018 were over EUR 26 billion (in 2017, the revenues amounted to EUR 5.6 billion) [62]. The EU ETS Directive requires that at least $50 \%$ of such revenues should be dedicated to climate and energy related purposes [63]. In reality, Member States have reported to the Commission that they have spent or planned to spend approximately $80 \%$ of the auction revenues for these purposes in 2017 [62]. However, there are claims that information on spending the ETS revenues on the climate and energy-related purposes from certain Member States is either not sufficiently detailed or is even 
misleading [64]. This suggests a low likelihood that any share of ETS revenues enabled financing of the SM TIS development. In this sense, the EU GHG emissions allowance trading scheme can be regarded as financial instrument that is not effectively used to support the SM TIS development.

White certificates:

White certificate obligations specify energy saving targets for companies and enable them to trade energy savings certificates. An evaluation of the possibility of introducing a "white certificate" scheme at the EU level has demonstrated that it would entail disproportionate administrative costs and that there was a threat that the resulting benefits would be concentrated only in a few Member States [9]. Therefore, the white certificate schemes have been introduced only in several EU Member States, inter alia in Italy, Finland and Poland.

There is no EU-level regulation for white certificates that would require or even only encourage the Member States that have introduced the white certificates to consider SM deployments as projects eligible for awarding white certificates. Therefore, white certificates can be regarded as financial instruments that are not effectively used at the EU level to support the SM TIS development.

\subsubsection{Soft Instruments}

SM deployment is not only a technical issue but also requires taking into account socio-economic areas [65]. In this context, soft measures may be important instruments for gaining acceptance for SM and ensuring effective roll-out across the EU [66].

\section{Endorsement Label}

Endorsement labels for SM in the EU are used at the level of individual Member States, e.g., in Germany. This type of soft instrument is not effectively used at EU-level to support SM TIS. Yet some national endorsement labels are of transnational character. For instance, the British Smart Meter Device Assurance (SMDA) scheme requires smart meters and related devices in Great Britain to be examined by NMi, a Dutch independent test house that conducts testing of smart meters [67]. Even though there is no EU-level single scheme for smart meter endorsement labels, it should be noted that also nonendorsement labels (labels discouraging a smart meter installation) have not gained any EU wide popularity. This is the case in the US, where online shops offer purchasing such labels in large quantities. In addition, in France, anti-Linky stickers (Linky is the smart meter to be rolled-out in France) are circulated [68].

\section{Information Campaigns}

SM roll-outs as complex socio-technical programmes require a comprehensive public communication framework-not only informing, but also involving consumers in the process [69]. Wide-ranging informational strategies that thoroughly satisfy consumers' needs in all phases of behavioural change are needed [70]. To this end, information campaigns on SM in the EU have been organised both at the EU level, e.g., by EDSO and ESMIG [71], as well as at the level of individual Member States, e.g., in the UK [54]. However, anti-SM information campaigns are also running in some Member States, e.g., in France, where Plateforme Opérationnelle anti-Linky has been established, warning households of the alleged increases in energy prices, electrosmog, no benefits for customers or increased fire risk [72]. National "Stop Linky" days were organised during which many municipalities arranged informational meetings [68]. As a result, 797 French local communities (less than 3\% of all communities in France) advised their residents to refuse smart meter installations [73].

Due to the fact that information campaigns do not provide sufficient response to the emerging anti-SM movements at national Member States' level, they can be regarded as soft instruments that are used in a limited scale at the EU-level to support SM TIS. 
Negotiated Agreements (Public-Private Sector)

No EU-level negotiated agreements (e.g., between the European Commission and EDSO) for SM have been identified. Such measures can be regarded as soft instruments that are not used for the support of the SM TIS development at the EU level.

Public Voluntary Schemes

No EU-level public voluntary schemes for SM have been identified. However, such schemes are successfully established in other policy areas of the Commission, e.g., the HR Excellence for Research scheme, voluntarily adopted by research institutions in the EU. Similar to the negotiated agreements, Public Voluntary Schemes can be regarded as soft instruments that are not used for the support of the SM TIS development at the EU level.

\section{Unilateral Commitments (Private Sectors)/EMSs}

No EU-level unilateral commitments of private sector (e.g., organisation of DSOs-EDSO), setting voluntary SM targets have been identified. This type of measures can be also regarded as soft instruments that are not used for the support of the SM TIS development at the EU level.

\section{Discussion}

\subsection{Innovating Actors}

SM development still remains a dynamic politically-driven process in the EU, entailing a high business risk, which in turn requires the involvement of many actors both from the supply and demand sides as well as many public bodies. They may have different, even opposed, interests in developing SM or some of these interests may be neutral. It is rather standard that in policy documents or later in pilot projects there is no clear assessment of costs and benefits allocated to the parties involved. The driving impulses come from public authorities, especially the European Commission, responsible for the implementation of the EU energy policy in its areas around SM.

\subsection{Knowledge Development and Exchange}

The high number of overlapping SM standards may prevent the EU SM stakeholders from realising economies of scale and ensuring interoperability. Moreover, many energy companies opt for SM deployments that are inexpensive and they ensure ownership of the communication channels, which may create bottlenecks in the future. In this context, introducing complementary products or services on the EU single market might be challenging. Therefore, encouraging standards convergence and collaboration between stakeholders (especially on standardisation) is needed. The EU mandate (M/441) entrusted to the CEN, the CENELEC and the ETSI to coordinate efforts towards harmonisation of SM standards can serve as a noteworthy good example in this respect [41].

\subsection{Actors' Vision and Expectations}

The EU-level actors' vision for the SM TIS development is evolving in terms of both industrial design and policy goals. As far as the first area is concerned, a lack of shared language about basic software and service concepts inhibits the SM market [74]. As far as the latter area is concerned, the public policy is the major enabler of the SM development at the EU level. Even though the EU-level obligation scheme for SM deployments in countries with a positive CBA result is a major instrument accelerating the SM TIS development, the rationale of the EU institutions behind it has been changing over time. In the beginning, the main goal of SM widespread deployment at the EU level was to promote energy efficiency (Article 3 of the ED). However, recently this goal has been extended to include also the final customers' empowerment (Article 19 of the EDR), e.g., through the integration of SM with Home Energy Management Systems. The adaptation of vision and expectation to the new 
experiences and knowledge collected in the process of TIS development can be regarded as a positive phenomenon, illustrating the learning process of the leading SM TIS actors in the EU. This observation also suggests that the legitimation of SM TIS (the process of acquiring a social acceptance of new technologies [13]), whose central features are actors' vision as well regulative alignment, is evolving. In this sense our findings provide further evidence on the importance of this process, also considered as one of the TIS functions, in the wider context of analysis of TIS dynamics.

Furthermore, in this context our findings provide potential explanations why TIS dynamic analysis performed not at country level but at multi-country (such as the EU level) can be challenging. Existing TIS dynamic modelling approaches, e.g., performed for dynamic modelling of cost allocation [75] or cost recovery [15] of SM roll-outs, are not designed to account for high heterogeneity of energy pricing (tariffs) and other country-based parameters of institutional environment in a multi-country context. In view of this fact, our results concerning SM TIS also suggest that further research is needed to develop fully-fledged dynamic analyses of decarbonisation-relevant TIS at EU level, in view of the inherent complexity of their institutional environments, e.g., concerning diverse technical standards across the EU.

\subsection{Market Formation and Governance}

Smart meters are considered key means allowing consumers to reap the benefits from the energy markets digitalisation and to access dynamic electricity pricing. The principal driver in the EU-level policy instruments to reach these objectives are the regulations, especially the obligation scheme, the sectoral standards and the net metering regulations encouraging replacement of meters. Furthermore, a strong push for SM development formation comes from economic and financial instruments, especially the R\&D funding and the EU-level regulations to introduce dynamic pricing tariffs. On the other hand, the major barriers in the EU-level policy instruments concern a limited use of soft instruments (e.g., the endorsement labels, information campaigns and voluntary approaches), no tax reliefs of exemptions for SM industrial stakeholders and limited consideration for SM in the building regulations (e.g., EPBD).

In this context, the findings of our analysis can be regarded as a useful input for further research on nonequilibrium dynamics and simulation models that consider the intertemporal aspects of market formation and interactions between actor groups and impacts of different interventions, as performed inter alia by Dehdarian et al. [15]. Our findings also extend the scope of policy instruments that have been so far considered as relevant for cost recovery of SM deployment, going beyond just regulated network tariffs and consumer bills [15]. We have demonstrated that the policy instruments portfolio that significantly influences the roll-outs in the EU is much wider than just financial or fiscal instruments. On the contrary, in view of the high heterogeneity of tariffs across the EU, one can claim that these policy instruments are not the core policy instruments enabling SM diffusion and market formation that is observed in the EU.

\subsection{Resources and Sustainability}

SM deployments do not require substantial amounts of materials, given the relatively small size of the devices. However, also from the sustainability point of view, the EU-level policies enabling the SM TIS development are not fully following-up on the fundamental purpose of SM deployments, i.e., energy saving. A limited consideration for supporting SM deployments in the EU-level regulations for market-based instruments (e.g., GHG allowances trading scheme, white certificates) aimed at improving energy efficiency may stem from the challenges with verifying the energy savings resulting from smart meter installations. As far as the SM demand for financial resources is concerned, in 2014 the European Commission estimated that EUR 45 billion would be necessary to install 200 million smart meters for electricity (representing approximately $72 \%$ of all European consumers) and 45 million smart meters for gas (around 40\% of consumers) by 2020 [76]. By comparison, if this investment was to be covered by the EU budget, it would represent approximately $4 \%$ of it [77]. From the point of view of 
ensuring external funding for SM deployment, the EU-level financial mechanisms provide significant support. For instance, a substantial part of the deployment of SM in the UK was the subject of the biggest loan which the European Investment Bank signed under the EFSI in 2015 [78]. Therefore, it is not the financing or materials that may turn out to be a barrier for SM development in the EU. Limited evidence is available to verify if the human (labour) resources available are sufficient and adequate for a successful large-scale roll-out of SM at the EU-level-further research on this subject would be needed. According to the experience of some EU Member States, for instance, smart meter installers are key for ensuring active engagement of households, sustaining their interest in considering their energy use and in committing to saving energy [79].

\section{Conclusions}

A major enabler for EU-level SM TIS is the clear, yet evolving vision of EU-level actors for SM deployment, founded on the grounds of energy conservation and empowerment of customers. Even though the objectives for smart meter penetration rates might have been set over ambitiously, they have contributed directly not only to the introduction of top-down obligation schemes at MS levels (e.g., in the UK), but also to bottom-up, voluntary initiatives of local stakeholders, e.g., DSOs in Poland who started the SM roll-outs ahead of any nationally binding regulations. Several EU-level regulations (e.g., support to net metering), government procurement, RD\&D funding as well as the EU push for dynamic pricing tariffs can be recognised as further significant enablers for the SM TIS development.

On the other hand, the major barrier for the EU-level is that the SM TIS development is an inadequate, insufficient regulatory framework for SM roll-outs, which does not ensure interoperability, data protection and security standards, a competition for the best solutions or organisational effectiveness of SM roll-outs at the national level. The product standards covering common minimum functional requirements of SM systems specified at the EU level can be considered as general and not sufficiently detailed to enable full exploitation of the EU internal market potential for cross-border flow of products and services. Several other regulations (e.g., on auditing), financial instruments (e.g., tax reliefs or exemptions, GHG emission allowances trading scheme) and soft instruments are not effectively used, creating other substantial barriers for the SM TIS development.

Author Contributions: Conceptualisation, M.K. and T.S.; methodology, T.S.; validation, T.S., and K.K.; investigation, M.K. and K.K.; resources, T.S.; data curation, M.K.; writing-original draft preparation, M.K.; writing-review and editing, K.K. and T.S.; visualisation, M.K.; supervision, T.S.; project administration, T.S.; funding acquisition, T.S. All authors have read and agreed to the published version of the manuscript.

Funding: The article has been prepared under the Project INNOPATHS: Innovation pathways, strategies and policies for the Low-Carbon Transition in Europe. The project has received funding from the European Union's Horizon 2020 research and innovation programme under grant agreement No. 730403.

Acknowledgments: We are thankful to Elena Verdolini, Assistant Professor in Political Economy, Dipartimento di Giurisprudenza, Università degli Studi di Brescia, Italy, for her advice and professional assistance in the design of our research as well as preliminary review. We are also grateful to Ewa Stefaniak for her diligent proofreading of this paper and to four anonymous reviewers for their valuable comments on earlier version of the manuscript.

Conflicts of Interest: The authors declare no conflict of interest. The funder had no role in the design of the study; in the collection, analyses, or interpretation of data; in the writing of the manuscript, or in the decision to publish the results.

\section{Glossary}

The following abbreviations were used in this manuscript:

AMI Advanced Metering Infrastructure

AMR Advanced Metering Reading

BB Broad Band

CAGR Compound Annual Growth Rate

CBA Cost Benefit Analysis

CEN European Committee for Standardization

CENELEC European Committee for Electrotechnical Standardization 


\begin{tabular}{|c|c|}
\hline CF & Cohesion Fund \\
\hline DSO & Distribution System Operator \\
\hline EC & European Commission \\
\hline ED & Electricity Directive \\
\hline EDR & Electricity Directive Recast \\
\hline EDSO & European Distribution System Operators \\
\hline EED & Energy Efficiency Directive \\
\hline EFSI & European Fund for Strategic Investment \\
\hline EIB & European Investment Bank \\
\hline EPBD & Energy Performance of Buildings Directive \\
\hline ERDF & European Regional Development Fund \\
\hline ESD & Energy Services Directive \\
\hline ESMIG & European Smart Metering Industry Group \\
\hline ESOs & European Standardization Organizations \\
\hline ETS & Emissions Trading System \\
\hline ETSI & European Telecommunications Standards Institute \\
\hline EU & European Union \\
\hline GHG & Greenhouse Gas \\
\hline GPRS & General Packet Radio Services \\
\hline GSM & Global System for Mobile Communications \\
\hline H2020 & Horizon 2020— the EU Framework Programme for Research \& Innovation \\
\hline ICT & Information and Communication Technologies \\
\hline IEC & International Electrotechnical Commission \\
\hline IEEE & Institute of Electrical and Electronics Engineers \\
\hline IoT & Internet of Things \\
\hline MS & Member State \\
\hline NB & Narrow Band \\
\hline PLC & Power Line Communication \\
\hline PON & Passive Optical Network \\
\hline$R \& D$ & Research and Development \\
\hline RF-Mesh & Radio Frequency-Mesh \\
\hline RMR & Remote Meter Reading \\
\hline SM & Smart Meter, Smart Metering \\
\hline SM-CG & Smart Meters Coordination Group \\
\hline SMDA & Smart Meter Device Assurance \\
\hline TIS & Technology Innovation System \\
\hline xDSL & X Digital Subscriber Line \\
\hline 6LoWPAN & IPv6 over Low -Power Wireless Personal Area Networks \\
\hline
\end{tabular}

\section{References}

1. Koponen, P.; Rochas, C. Definition of Smart Metering and Applications and Identification of Benefits. 2008. Available online: https://www.vtt.fi/inf/julkaisut/muut/2008/Definition_of_smart_metering_and_applications_and_ identification_of_benefits.pdf (accessed on 20 January 2020).

2. European Commission. COM(2016) 864 final/2 Proposal for a Directive of the European Parliament and of the Council on Common Rules for the Internal Market in Electricity (Recast); European Commission: Brussels, Belgium, 2017.

3. CEN/CENELEC/ETSI Smart Meters Coordination Group. Functional Reference Architecture for Communications in Smart Metering Systems; s.1.: CEN, CENELEC and ETSI. 2011. Available online: ftp://ftp.cen.eu/cen/Sectors/List/Measurement/Smartmeters/CENCLCETSI_TR50572.pdf (accessed on 20 January 2020).

4. UK House of Commons-Communities and Local Government Committee. Existing Housing and Climate Change: Seventh Report of Session 2007-2008; House of Commons: London, UK, 2008. 
5. Eurelectric. Eurelectric's Position Paper: Building a European Smart Metering Framework Suitable for all Retail Electricity Customers; Eurelectric: Brussels, Belgium, 2008.

6. European Commission. Digital Single Market 2018. Available online: https://ec.europa.eu/commission/ priorities/digital-single-market_en (accessed on 20 January 2020).

7. Ristori, D. A new era: The Digitalisation of Europe's Energy System-EURACTIV.com. Euractiv. 2017. Available online: https://www.euractiv.com/section/electricity/opinion/a-new-era-the-digitalisation-ofeuropes-energy-system/ (accessed on 20 January 2020).

8. European Parliament; Council of the European Union. Directive 2006/32/EC of the European Parliment and the Council of 5 April on Energy End-Use Efficiency and Energy Services and Repealing Council Directive 93/76/EEC; European Parliament and Council of the European Union: Brussels, Belgium, 2006; pp. 12-25.

9. European Parliament; Council of the European Union. Directive 2012/27/EU of 25 October 2012 on Energy efficiency, Amending Directives 2009/125/EC and 2010/30/EU and Repealing Directives 2004/8/EC and 2006/32/EC, no. October; European Parliament and Council of the European Union: Brussels, Belgium, 2012; pp. 1-56.

10. House of Commons Science \& Technology Committee. Evidence Check: Smart Metering; s.l.: House of Commons. 2016. Available online: https://publications.parliament.uk/pa/cm201617/cmselect/cmsctech/161/ 161.pdf (accessed on 20 January 2020).

11. Hekkert, M.P.; Suurs, R.A.A.; Negro, S.O.; Kuhlmann, S.; Smits, R.E. Functions of innovation systems: A new approach for analysing technological change. Technol. Forecast. Soc. Chang. 2007, 74, 413-432. [CrossRef]

12. Bergek, A.; Hekkert, M.; Jacobsson, S. Functions in Innovation Systems: A Framework for Analysing Energy System Dynamics and Ident; RIDE/IMIT; Edward Elgar Publishing: Cheltenham, UK, 2008.

13. Bergek, A.; Jacobsson, S.; Sandén, B.A. Legitimation' and 'development of positive externalities': Two key processes in the formation phase of technological innovation systems. Technol. Anal. Strateg. Manag. 2008, 20, 575-592. [CrossRef]

14. Hekkert, M.; Heimeriks, G.; Harmsen, R. Technological Innovation System Analysis; Utrecht University: Utrecht, The Netherlands, 2011.

15. Dehdarian, A. Scenario-based system dynamics modeling for the cost recovery of new energy technology deployment: The case of smart metering roll-out. J. Clean. Prod. 2018, 178, 791-803. [CrossRef]

16. Peñasco, C.; Verdolini, E.; Larkin, P. Innopaths Prototype of Policy Evaluation Tool. 2018. Available online: https://ec.europa.eu/research/participants/documents/downloadPublic?documentIds= 080166e5bace730c\&appId=PPGMS (accessed on 20 January 2020).

17. Press, C. Hermann Aron's Electricity Meters: Physics and Invention in Late Nineteenth-Century Germany. Hist. Stud. Nat. Sci. 2013, 39, 444-484.

18. Lewczuk, Ł. Do pomiaru poboru energii-liczniki energii elektrycznej; Fachowy Elektr. 2017. Available online: http://www.fachowyelektryk.pl/technologie/zasilanie/2070-do-pomiaru-poboru-energii-licznikienergii-elektrycznej.html (accessed on 3 January 2020).

19. Avancini, D.B.; Rodrigues, J.J.P.C.; Martins, S.G.B.; Rabêlo, R.A.L.; Al-Muhtadi, J.; Solic, P. Energy meters evolution in smart grids: A review. J. Clean. Prod. 2019, 217, 702-715. [CrossRef]

20. Kamat, V.N. Enabling an electrical revolution using smart apparent energy meters \& tariffs. In Proceedings of the 2011 Annual IEEE India Conference, Hyderabad, India, 16-18 December 2011.

21. Berg Insight. Smart Metering in Europe 2017, 14th ed.; Berg Insight: Gothenburg, Sweden, 2018.

22. Strother, N.; Meters, B.L.S. Smart Electric Meters, Advanced Metering Infrastructure, and Meter Communications: Global Market Analysis and Forecasts; Analytical Spectral Devices, Inc.: Boulder, CO, USA, 2014.

23. ACER; CEER. Annual Report on the Results of Monitoring the Internal Electricity and Natural Gas Markets in 2017. Available online: https:/www.acer.europa.eu/Official_documents/Acts_of_the_Agency/Publication/ MMR\%202017\%20-\%20ELECTRICITY.pdf (accessed on 3 January 2020).

24. Uribe-Pérez, N.; Hernández, L.; de la Vega, D.; Angulo, I. State of the Art and Trends Review of Smart Metering in Electricity Grids. Appl. Sci. 2016, 6, 68. [CrossRef]

25. Berg Insight. Smart Metering in Europe, 13th ed.; Berg Insight: Gothenburg, Sweden, 2017.

26. Ahmad, A. Smart Grid as a Solution for Renewable and Efficient Energy; IGI Global: Hershey, PA, USA, 2016.

27. Andreadou, N.; Guardiola, M.O.; Fulli, G. Telecommunication technologies for smart grid projects with focus on smart metering applications. Energies 2016, 9, 375. [CrossRef]

28. Mas, M.; Fernández de Guevara, J.; Robledo, J.C.; Cardona, M.; López-Cobo, M.; Righi, R.; Samoili, S. An Analysis of ICT RED in the EU and Beyond; European Commission: Luxembourg, 2018. 
29. ResearchAndMarkets.com. The Cybersecurity Market in Europe 2018-2023: A +\$47 Billion Market Opportunity. 2018. Available online: https://www.marketsandmarkets.com/Market-Reports/cyber-securitymarket-505.html? (accessed on 20 January 2020).

30. Colak, I.; Fulli, G.; Sagiroglu, S.; Yesilbudak, M.; Covrig, C.F. Smart grid projects in Europe: Current status, maturity and future scenarios. Appl. Energy 2015, 152, 58-70. [CrossRef]

31. Iqtiyaniilham, N.; Hasanuzzaman, M.; Hosenuzzaman, M. European Smart Grid Prospects, Policies, and Challenges. Renew. Sustain. Energy Rev. 2016, 67, 776-790. [CrossRef]

32. Smart Energy International. Global Trends in Smart Metering 2018. Available online: https://www.smartenergy.com/magazine-article/global-trends-in-smart-metering/ (accessed on 20 January 2020).

33. Accenture. Realizing the Full Potential of Smart Metering; s.l.: Accenture. 2013. Available online: https://www.accenture.com/t20160413t230144_w__/us-en/_acnmedia/accenture/conversion-assets/ dotcom/documents/global/pdf/industries_9/accenture-smart-metering-report-digitally-enabled-grid.pdf (accessed on 20 January 2020).

34. Papakonstantinou, V.; Kloza, D. Legal Protection of Personal Data in Smart Grid and Smart Metering Systems from the European Perspective. In Smart Grid Security; Goel, S., Hong, Y., Papakonstantinou, V., Kloza, D., Eds.; Springer: London, UK, 2015; pp. 41-129.

35. European Parliament; Council of the European Union. Directive 2010/31/EU of 19 May 2010 on the Energy Performance of Buildings; European Parliament and Council of the European Union: Brussels, Belgium, 2010; pp. 13-35.

36. Minister Infrastruktury i Rozwoju. Obwieszczenie Ministra Infrastruktury i Rozwoju z dnia 17 lipca 2015 r. Załacznik Rozporzadzenie Ministra Infrastruktury z dnia 12 kwietnia 2002 r. w sprawie warunków technicznych jakim powinny odpowiadać budynki i ich usytuowanie; Ministerstwo Infrastruktury i Rozwoju: Warsaw, Poland, 2015.

37. European Commission. Standardisation Mandate to CEN, CENELEC and ETSI in the Field of Measuring Instruments for the Development of an Open Architecture for Utility Meters Involving Communication Protocols Enabling Interoperability; European Commission: Brussels, Belgium, 2009.

38. Smart Metering-Cen-Cenelec 2018. Available online: https://www.cencenelec.eu/standards/sectors/ sustainableenergy/smartmeters/pages/default.aspx (accessed on 20 January 2020).

39. European Commission. (2012/148/EU) Commission Recommendation of 9 March 2012 on Preparations for the Roll-out of Smart Metering Systems; European Commission: Brussels, Belgium, 2012.

40. European Parliament. European Parliament Legislative Resolution of 26 March 2019 on the Proposal for a Directive of the European Parliament and of the Council on Common rules for the Internal Market in Electricity (Recast) (COM(2016)0864-C8-0495/2016-2016/0380(COD)); European Parliament: Brussels, Belgium, 2019.

41. Erlinghagen, S.; Lichtensteiger, B.; Markard, J. Smart meter communication standards in Europe-A comparison. Renew. Sustain. Energy Rev. 2015, 43, 1249-1262. [CrossRef]

42. Giordano, V.; Onyeji, I.; Fulli, G.; Jiménez, M.S.; Filiou, C. Guidelines for Cost Benefit Analysis of Smart Metering Deployment; European Commission: Luxembourg, 2012.

43. European Commission Joint Research Centre. Smart Metering Deployment in the European Union 2019. Available online: https://ses.jrc.ec.europa.eu/smart-metering-deployment-european-union (accessed on 15 April 2019).

44. European Commission. SWD(2014) 189 Final. Cost-Benefit Analyses E State of Play of Smart Metering Deployment in the EU-27; European Commission: Brussels, Belgium, 2014.

45. European Commission. A Digital Agenda for Europe COM(2010)245 Final; European Commission: Brussels, Belgium, 2010.

46. European Commission. Smart Grids: From Innovation to Deployment; European Commission: Brussels, Belgium, 2011.

47. European Council. Council Conclusion 04.02.2011; European Council: Brussels, Belgium, 2011.

48. Newbery, D.; Pollitt, M.G.; Ritz, R.A.; Strielkowski, W. Market design for a high-renewables European electricity system. Renew. Sustain. Energy Rev. 2018, 91, 695-707. [CrossRef]

49. European Commission. What Is Horizon 2020? 2019. Available online: https:/ec.europa.eu/programmes/ horizon2020/what-horizon-2020 (accessed on 20 January 2020).

50. Faruqui, A.; Harris, D.; Hledik, R. Unlocking the $€ 53$ billion savings from smart meters in the EU: How increasing the adoption of dynamic tariffs could make or break the EU's smart grid investment. Energy Policy 2010, 38, 6222-6231. [CrossRef] 
51. European Commission. Energy prices and costs in Europe \{SWD(2019) 1 Final\}; European Commission: Brussels, Belgium, 2019.

52. Ebrill, A. Regulators' Monitoring of Consumer Protection and Retail Markets; Brussels, Belgium. 2018. Available online: https://slideplayer.com/slide/15386776/ (accessed on 20 January 2020) .

53. European Commission. The EU's Main Investment Policy 2019. Available online: https://ec.europa.eu/ regional_policy/en/policy/what/investment-policy/ (accessed on 20 January 2020).

54. European Parliament; Council of the European Union. Regulation (EU) No 1301/2013 of the European Parliament and of the Council of 17 December 2013 on the European Regional Development Fund and on Specific Provisions Concerning the Investment for Growth and Jobs Goal and Repealing Regulation (EC) No 1080/20; no. 1301; European Parliament and Council of the European Union: Brussels, Belgium, 2013; p. 470.

55. European Parliament; Council of the European Union. Regulation (EU) No. 1300/2013 of the European Parliament and of the Council of 17 December 2013 on the Cohesion Fund and Repealing Council Regulation (EC) No. 1084/2006; European Parliament and Council of the European Union: Brussels, Belgium, 2013.

56. Ministerstwo Inwestycji i Rozwoju. Mapa Dotacji UE 2019. Available online: http://www.mapadotacji.gov.pl (accessed on 20 January 2020).

57. Ministerstwo Inwestycji i Rozwoju. Mapa Dotacji UE; Ministerstwo Inwestycji i Rozwoju: Warsaw, Poland, 2019.

58. European Investment Bank. 2015 EFSI Report From the European Investment Bank to the European Parliament and the Council on 2015 EIB Group Financing and Investment Operations under EFSI; s.l.: European Fund for Strategic Investment. 2015. Available online: https://www.eib.org/attachments/strategies/efsi_2015_report_ep_council_ en.pdf (accessed on 20 January 2020) .

59. European Commission. Investment Plan Results. 2019. Available online: https://ec.europa.eu/commission/ priorities/jobs-growth-and-investment/investment-plan-europe-juncker-plan/investment-plan-results/ (accessed on 2 May 2019).

60. European Commission. Taxation and Customs Union; European Commission: Brussels, Belgium, 2019.

61. Council of the European Union. Council Directive 2006/112/EC of 28 November 2006 on the Common System of Value Added Tax; Council of the European Union: Brussels, Belgium, 2006.

62. European Commission. Report from the Commission to the European Parliament and the Council: Report on the Functioning of the European Carbon Market. 2018. Available online: https://op.europa.eu/en/publicationdetail/-/publication/fa0fd864-0212-11e9-adde-01aa75ed71a1/language-en (accessed on 20 January 2020) .

63. European Parliament; Council of the European Union. Directive 2003/87/EC of the European Parliament and of the Council Establishing a Scheme for Greenhouse gas Emission Allowance Trading within the Community and Amending Council Directive 96/61/EC; European Parliament; Council of the European Union: Brussels, Belgium, 2003.

64. Wieczerzak-Krusińska, A. Budżet puchnie od dwutlenku. Parkiet. 2018. Available online: https://www. parkiet.com/Firmy/310089970-Budzet-puchnie-od-dwutlenku.html (accessed on 3 January 2020).

65. Bigerna, S.; Bollino, C.A.; Micheli, S. Socio-economic acceptability for smart grid development-A comprehensive review. J. Clean. Prod. 2016, 131, 399-409. [CrossRef]

66. Miller, C.A.; Richter, J.; O’Leary, J. Socio-energy systems design: A policy framework for energy transitions. Energy Res. Soc. Sci. 2015, 6, 29-40. [CrossRef]

67. NMi. NMi Announced as the Appointed SMDA Test House for Smart Meters in Great Britain 2017. Available online: https://www.nmi.nl/nmi-announced-appointed-smda-test-house-smart-meters-greatbritain/ (accessed on 2 April 2019).

68. Faure, C.; Schleich, J. Linky: Do smart meters actually help reduce electricity consumption? Conversat. 2018. Available online: http://theconversation.com/linky-do-smart-meters-actually-help-reduce-electricityconsumption-99395 (accessed on 3 January 2020).

69. Karlin, B. Public Acceptance of Smart Meters: Integrating Psychology and Practice. In Proceedings of the 2012 Summer Study on Energy Efficiency in Buildings, Pacific Grove, CA, USA, $12-17$ August 2012; pp. 102-113.

70. Nachreiner, M.; Mack, B.; Matthies, E.; Tampe-Mai, K. An analysis of smart metering information systems: A psychological model of self-regulated behavioural change. Energy Res. Soc. Sci. 2015, 9, 85-97. [CrossRef]

71. EDSO; ESMIG. My Smart Energy. 2014. Available online: http://my-smart-energy.eu/smart-meters (accessed on 20 January 2020). 
72. FranceInfo. 'Je N'ai pas Envie de Prendre des Risques Pour la Santé de mon Enfant': Comment des Anti-Linky ont Décidé D’attaquer Enedis en Justice. 2019. Available online: https://www.francetvinfo.fr/economie/linky/je-n-ai-pas-envie-de-prendre-des-risques-pour-la-sante-demon-enfant-comment-des-anti-linky-ont-decide-d-attaquer-enedis-en-justice_3134803.html (accessed on 20 January 2020).

73. La plateforme opérationnelle anti-Linky POAL. Les Communes qui ont Refusé le Compteur Linky_POAL_La Plateforme Opérationnelle Anti-Linky. 2019. Available online: https://www.poal. fr/appfree/carte-france-communes-refus-anti-non-linky.html (accessed on 20 January 2020).

74. Smart Energy International. Over 100 Million Smart Meters Adopt Head-End Software 'as a Service'. 2019. Available online: https://www.smart-energy.com/features-analysis/electricity-meters-ihs-markit/ (accessed on 9 May 2019).

75. Dehdarian, A.M. Three Essays on Methodologies for Dynamic Modeling of Emerging Socio-Technical Systems: The Case of Smart Grid Development; Ecole Polytechnique Fédérale de Lausanne: Lausanne, Switzerland, 2017.

76. European Commission. Benchmarking Smart Metering Deployment in the EU-27 with a Focus on Electricity COM(2014) 356 Final; European Commission: Brussels, Belgium, 2014.

77. European Commission. Integrated Financial Reporting Package Overview-Financial year 2017; European Commission: Brussels, Belgium, 2017.

78. EIB. Smart Meters Help Consumers Control Energy Bills. 2016. Available online: https://www.eib.org/en/ infocentre/stories/all/2016-january-02/get-smart.htm (accessed on 28 January 2019).

79. Darby, S.; Liddell, C. Communicating 'smartness': Smart meter installers in UK homes. Eceee Summer Study Proc. 2016, 9, 1991-2001.

(C) 2020 by the authors. Licensee MDPI, Basel, Switzerland. This article is an open access article distributed under the terms and conditions of the Creative Commons Attribution (CC BY) license (http://creativecommons.org/licenses/by/4.0/). 